Seasonal methane dynamics in high-elevation lakes in the Sierra

Nevada California: the role of elevation, temperature, organic matter, and inorganic nutrients

Elisabet Perez-Coronel ${ }^{\mathrm{a}^{*}}$; Stephen C. Hart ${ }^{\mathrm{b}}$ J. Michael Beman ${ }^{\mathrm{b}}$

${ }^{a}$ Environmental Systems Graduate Group. University of California Merced, Merced, USA; ${ }^{b}$ Department of Life \& Environmental Sciences and the Sierra Nevada Research Institute, University of California Merced, Merced, USA.

*Corresponding author: Elisabet Perez-Coronel. University of California Merced. e-mail for correspondence: eperezcoronel@ucmerced.edu

This manuscript has been submitted for publication to the Inland Waters journal. Please note that the manuscript has not yet been peer-reviewed nor accepted for publication. Subsequent versions of this manuscript may have slightly different content. If accepted, the final version of this manuscript will be available via the "peer-reviewed publication DOI" link on this webpage. Please feel free to contact the corresponding author; we welcome feedback. 


\section{Seasonal methane dynamics in high-elevation lakes in the Sierra \\ Nevada California: the role of elevation, temperature, organic matter, and inorganic nutrients}

\section{Abstract}

Freshwater lakes are important but poorly constrained sources of methane $\left(\mathrm{CH}_{4}\right)$ to the atmosphere due to high, but variable, rates of $\mathrm{CH}_{4}$ production, as well as limited and inconsistent measurements worldwide. Highelevation lakes have been particularly overlooked — despite their large numbers in mountain ranges around the world, and despite $\mathrm{CH}_{4}$ dynamics at high elevations may be altered by rapid increases in temperature due to climate change. We examined variations in surface $\mathrm{CH}_{4}$ concentrations and diffusive fluxes, temperature, dissolved organic matter (DOC), and inorganic nutrients in five montane lakes spanning multiple elevations in the Sierra Nevada of California. Over two years, we found strong and consistent seasonality in $\mathrm{CH}_{4}$ concentrations in lakes; higher concentrations were typically observed in the warmest months and lower concentrations in fall. Changes in $\mathrm{CH}_{4}$ concentrations were significantly related to temperature in the majority of the individual lakes $\left(r^{2}=0.43-\right.$ $0.81)$ and related to elevation $\left(r^{2}=0.39\right)$ and DOC $\left(r^{2}=0.30\right)$ across lakes. Methane concentrations in lakes at elevations $<3000$ m were strongly related to temperature, nitrite concentrations and elevation $\left(r^{2}=0.90\right)$, whereas at elevations $>3000 \mathrm{~m}, \mathrm{CH}_{4}$ correlated with dissolved inorganic nitrogen to dissolved inorganic phosphorus ratios and elevation $\left(r^{2}=\right.$ 
0.48). Our results expand on our understanding of temporal variations in $\mathrm{CH}_{4}$ and demonstrate substantial seasonality in $\mathrm{CH}_{4}$ concentrations and diffusive fluxes in freshwater lakes — suggesting that temporal variation should be considered in large-scale estimates, and may be a predictable function of elevation, temperature, organic matter, and nutrients.

Keywords: high-elevation lakes; lake biogeochemistry; methane concentrations; methane diffusive fluxes; montane lakes; seasonality

\section{Introduction}

Methane $\left(\mathrm{CH}_{4}\right)$ is a potent greenhouse gas with great influence on the world's climate (Hoegh-Guldberg et al. 2018; Reay et al. 2018). While anthropogenic emissions have increased atmospheric $\mathrm{CH}_{4}$ concentrations over the last century, an important baseline contribution of $\mathrm{CH}_{4}$ to the atmosphere comes from natural ecosystems (Conrad 2009; Kirschke et al. 2013). Methane emissions from freshwater lakes are a particularly significant, but poorly constrained, component of natural $\mathrm{CH}_{4}$ emissions. For example, the contribution of freshwater ecosystems (lakes and rivers) to the global $\mathrm{CH}_{4}$ budget is estimated to range from $12 \%$ to $32 \%$ (with uncertainties ranging from $2 \%$ to $47 \%$ ) of natural emissions (Saunois et al. 2016). More specifically, current estimates of the global $\mathrm{CH}_{4}$ total emissions from freshwater lakes and impoundments range an order of magnitude, from 69 to $204 \mathrm{Tg} \mathrm{CH}_{4}-\mathrm{C} \mathrm{yr}^{-1}$ (DelSontro et al. 2018). These uncertainties stem partly from the substantial spatial and temporal variability in $\mathrm{CH}_{4}$ cycling across and within freshwater lakes, as well as significant under-sampling of this variability. For instance, only a few hundred lakes have been sampled for $\mathrm{CH}_{4}$ emissions out an estimated total of 304 million lakes globally (Downing 2009; Bastviken et al. 2011), and only a handful of studies have measured $\mathrm{CH}_{4}$ variation over time (Xing et al. 2005; 
Casper et al. 2009; Palma-Silva et al. 2013; Natchimuthu et al. 2014; Martinez-Cruz et al. 2015). Clearly, additional studies are needed of the spatial and temporal heterogeneity in $\mathrm{CH}_{4}$ emissions from these ecosystems, as well as their potential controls (Tranvik et al. 2009; Bastviken et al. 2011; Reay et al. 2018).

Variations in $\mathrm{CH}_{4}$ concentrations in lake water columns are driven by microbial $\mathrm{CH}_{4}$ production (predominantly via methanogenesis in sediments) and consumption via microbial $\mathrm{CH}_{4}$ oxidation in surface sediments and the water column (Bastviken et al. 2004). Both of these processes can be altered by changes in environmental conditions and, in general, temperature seems to have a strong positive effect on both of them (Zeikus and Winfrey 1976; Duc et al. 2010; Palma-Silva et al. 2013; Lofton et al. 2014; Marotta et al. 2014; Sepulveda-Jauregui et al. 2018). Moreover, ecosystem-level analyses seem to indicate that as temperatures rise, $\mathrm{CH}_{4}$ lake concentrations and fluxes will also increase (Natchimuthu et al. 2014; Yvon-Durocher et al. 2014; Rasilo et al. 2015). However, much of our understanding of temperature regulation of $\mathrm{CH}_{4}$ concentrations in freshwater is derived from laboratory- or field-based experimental temperature manipulations. While these studies are extremely useful for isolating the effects of temperature from other variables, in situ temperature may vary in concert with other seasonally changing environmental properties, such as lake organic carbon (C) inputs and nutrients concentrations. For example, the quantities and types of organic $\mathrm{C}$ present in lakes during the year influence $\mathrm{CH}_{4}$ production (Conrad 1999), and this in turn is regulated by nutrient availability (Sepulveda-Jauregui et al. 2018). For $\mathrm{CH}_{4}$ consumption, on the other hand, temperature may only play a role when neither $\mathrm{CH}_{4}$ nor DO concentrations are limiting (Harrits and Hanson 1980; Liikanen et al. 2002; Martinez-Cruz et al. 2015). Collectively, these environmental factors may interact to 
influence $\mathrm{CH}_{4}$ production, consumption, and emissions. The degree to which temperature - versus other environmental factors - affects $\mathrm{CH}_{4}$ emissions from lakes remains largely unknown. Further characterization of this response is necessary as it could result in a positive climate feedback as global temperatures increase.

High-elevation regions are predicted to experience increased air temperatures, reduced lake ice cover, reduced snow-albedo, and changes in cloud cover as a result of climate change (Mountain Research Initiative EDW Working Group et al. 2015; O'Reilly et al. 2015; Sadro et al. 2019). Temperate montane lakes therefore could be disproportionately affected by climate change — including both increases in average temperatures, as well as changes in seasonal variability (e.g., reduced ice cover and a longer growing season). Importantly, high-elevation lakes can exhibit high $\mathrm{CH}_{4}$ concentrations and fluxes (McCrackin and Elser 2011), but $\mathrm{CH}_{4}$ cycling is rarely characterized in these lakes. Their contribution to the $\mathrm{CH}_{4}$ budget may be underrepresented in comparison to tropical or boreal lakes due to a lack of measurements (Saunois et al. 2016), even though they represent around 10\% of lakes globally (Verpoorter et al. 2014). The Sierra Nevada of California is home to thousands of such lakes (Melack and Stoddard 1991; Sickman et al. 2003), and this region already displays a long-term warming trend (Sadro et al. 2019). Snow-albedo feedbacks and changes in the type of precipitation will likely further increase warming and reduce snow pack melt in the decades to come (Walton et al. 2016; Sun et al. 2019).

Further reduction in snowpack melt and rain could also affect high-elevation lakes by altering nutrient inputs into freshwater lakes from snowmelt (Williams et al. 2001; Sickman et al. 2003). At the same time, increased nutrient loading from atmospheric 
deposition has been shown to alter algal communities and trophic dynamics in highelevation ecosystems (Baron et al. 2000; Elser et al. 2007; Elser et al. 2009). Atmospheric deposition is a significant source of nutrients to the Sierra Nevada (Aciego et al. 2017), where changes in nutrient limitation may already be occurring due to human activity in the adjacent San Joaquin Valley (Sickman et al. 2003). Such changes could consequently impact $\mathrm{CH}_{4}$ cycling in lakes by altering organic $\mathrm{C}$ sources and quantities to these ecosystems (Tranvik et al. 2009; West et al. 2016; Reay et al. 2018; Moser et al. 2019). Finally, recent research indicates that the combination of increased temperature and nutrient concentrations can strongly enhance lake $\mathrm{CH}_{4}$ production and ebullition (Davidson et al. 2018; Sepulveda-Jauregui et al. 2018). An improved understanding of the effects of environmental variation on $\mathrm{CH}_{4}$ emissions in this ecosystem will help us account for future changes in $\mathrm{CH}_{4}$ fluxes and better predict longterm climate trends.

We used large natural variations in temperature over time and with increasing elevation to determine the potential importance of temperature controls on $\mathrm{CH}_{4}$ emissions from montane lakes. High-elevation lakes in the Sierra Nevada represent an ideal experimental system for examining temperature effects on $\mathrm{CH}_{4}$ emissions within natural freshwater ecosystems because of these strong natural variations. Over two years, we quantified $\mathrm{CH}_{4}$ concentrations and diffusive emissions in five lakes spanning an elevation gradient in the Sierra Nevada, California (Fig. 1). In addition to temperature variation, we measured two main categories of environmental variation that are likely to affect $\mathrm{CH}_{4}$ emissions: nutrient (ammonium, nitrite, nitrate, phosphate) concentrations and availability and organic $\mathrm{C}$ production and properties (dissolved organic $\mathrm{C}$ and specific UV absorbance at $254 \mathrm{~nm}$ ). Our aim was to answer the following research 
questions: 1) To what degree do $\mathrm{CH}_{4}$ concentrations vary spatially over an elevation gradient and temporally over the seasons in high-elevation lakes, and how does this compare with other lake types? and 2) how much of the variation in $\mathrm{CH}_{4}$ concentrations within and among lakes can be explained by seasonal fluctuations in environmental parameters (independently or collectively) such as temperature, nutrients and organic C concentrations, as well as lake intrinsic characteristics (e.g., elevation)? We hypothesized that temperature and nutrient concentrations would have the greatest effect on $\mathrm{CH}_{4}$ concentrations in surface lake water, especially at higher elevations where temperatures are rapidly increasing, and landscapes characteristics contribute less allochthonous nutrient sources to lakes.

\section{Materials and methods}

\section{Study site and sample collection}

Five high-elevation lakes in the Sierra Nevada of California were selected based on preliminary data showing high microbial production and consumption rates and methanogen and $\mathrm{CH}_{4}$-oxidizer abundances (Hayden and Beman 2016). Lukens, Lower Cathedral, Upper Cathedral, Lower Gaylor, and Upper Gaylor Lakes have an elevation range of 2489 to $3185 \mathrm{~m}$, and mean summer surface water temperature range of 12.8 to 17.2 ${ }^{\circ} \mathrm{C}$ (Fig. 1). Water samples were collected every $\sim 2-3$ weeks in the littoral and limnetic zones from July to November of 2016 and 2017 (sampling season) due to field site inaccessibility from December to June. Samples were collected at $0.1 \mathrm{~m}$ depth with a previously acid washed plastic or glass containers to measure: $\mathrm{CH}_{4}$, nitrite $\left(\mathrm{NO}_{2}{ }^{-}\right)$, nitrate $\left(\mathrm{NO}_{3}{ }^{-}\right)$, ammonium $\left(\mathrm{NH}_{4}{ }^{+}\right)$and phosphate $\left(\mathrm{PO}_{4}{ }^{3-}\right)$ concentrations; and dissolved organic carbon (DOC). Temperature (T) and dissolved oxygen (DO) were measured on site using a ProODO YSI probe (YSI Inc., Yellow Springs, OH, USA). 


\section{Methane measurements}

Methane concentrations were measured via headspace equilibration and gas chromatography. In brief, triplicate water samples were collected directly into $170 \mathrm{ml}$ glass vials, capped with halogenated butyl stoppers, and crimped with aluminum seals to avoid gas loss. Twenty-five $\mathrm{ml}$ of water was then replaced with $25 \mathrm{ml}$ of air collected on site, while air samples were collected into 12-mL Labco Exetainer vials (Labco Ltd., Lampeter, Ceredigion, UK). One hundred seventy $\mathrm{mL}$ glass vials containing water and headspace were shaken for 2 minutes to reach equilibration, and the headspace was collected with a gas-tight syringe; headspace gas samples were immediately transferred into 12-mL Exetainer vials. Triplicate samples were later analyzed using a Shimadzu GC-2014 gas chromatograph with flame ionization detection (FID) for $\mathrm{CH}_{4}$ (Weiss 1981). Samples were analyzed within 2-3 months of collection (a time period of up to 15 weeks has been tested and found to result in no significant change in $\mathrm{CH}_{4}$ concentrations, with $2 \%$ or less decrease in $5 \mathrm{ppm} \mathrm{CH}_{4}$ concentration from storage). Methane standards (Air Liquide, Houston, Texas USA) ranged from 1.5 to $333 \mathrm{ppm}$ and bracketed every 15 samples; standard curve $r^{2}$ values ranged from 0.997 - 0.999 across different runs. Headspace $\mathrm{CH}_{4}$ concentration measurements were then used to calculate $\mathrm{CH}_{4}$ concentration in lake water based on Henry's law of equilibrium (Yamamoto et al. 1976). 


\section{Diffusive methane fluxes}

Diffusive $\mathrm{CH}_{4}$ fluxes were calculated with the following equation:

$$
F=k\left(C_{w}-C_{a}\right)
$$

where $\mathrm{F}$ is the flux, $k$ is the gas transfer coefficient, $\mathrm{C}_{\mathrm{w}}$ is the dissolved $\mathrm{CH}_{4}$ concentration in the water, and $\mathrm{C}_{\mathrm{a}}$ is the concentration of $\mathrm{CH}_{4}$ in the air. The parameter $k$ was estimated from wind-speed data collected from meteorological stations (White Wolf, Tuolumne Meadows, and Tioga Pass stations, each selected for their close proximity to Lukens, Cathedral, and Gaylor Lakes respectively) in Yosemite National Park maintained by the California Department of Water Resources (http://cdec.water.ca.gov) and the relationship developed by Cole and Caraco (1998) for low-wind speeds:

$$
k_{600}=2.07+0.215 U_{10}^{1.7}
$$

where $k_{600}$ is the gas coefficient normalized to Schmidt number (Sc) 600, and $U_{10}$ is the wind speed adjusted to $10 \mathrm{~m}$ following Amorocho and DeVries (1980).

The $k_{600}$ values were converted to $\mathrm{k}$ values using the equation from Bartosiewicz et al. (2015):

$$
k=k_{600}(S c / 600)^{c},
$$

where $k$ is the gas transfer coefficient, c equals -0.67 according to Guérin et al. (2007), and Sc is calculated following Wanninkhof (2014). While there are acknowledged uncertainties associated with calculating $k$ from wind-speed models, we aimed to provide an estimate of diffusive emissions from high-elevation lakes that is lacking in 
the literature. However, these estimated diffusive fluxes were not included in further statistical analyses.

\section{Nutrients and organic matter}

For nutrient measurements, water collected in the lakes was filtered $(0.22 \mu \mathrm{m})$ and analyzed for $\mathrm{NH}_{4}{ }^{+}, \mathrm{NO}_{2}{ }^{-}, \mathrm{NO}_{3}{ }^{-}$, and $\mathrm{PO}_{4}{ }^{3-}$. Ammonium and $\mathrm{NO}_{2}{ }^{-}$were analyzed using a Trilogy Laboratory Fluorometer (Turner Designs; San Jose, CA, USA) with $\mathrm{NH}_{4}{ }^{+}$and $\mathrm{NO}_{2}{ }^{-}$modules using the fluorescent method of Holmes et al. (1999) and the sulfanilamide coloration method (APHA 1998), respectively. Samples were frozen at $-20{ }^{\circ} \mathrm{C}$ after collection and stored for no longer than two months (Chapman and Mostert

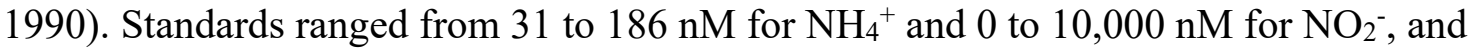
standard curve $r^{2}$ values ranged from 0.997 to 0.999 for different runs. Nitrate and phosphate were analyzed using flow injection analysis on a QuikChem 8000 (Zellweger Analytics; Concord, ON, CA) at the University of California, Santa Barbara, Marine Sciences Institute Analytical Laboratory (standard curves $r^{2}=0.996$ and $r^{2}=0.997$, respectively).

Samples for DOC were only collected in 2017 . Water was filtered through a GFF Whatman filter and collected in glass vials what had been combusted previously in a muffle furnace. Samples for DOC were acidified to $\mathrm{pH} 2$ with $2 \mathrm{M} \mathrm{HCl}$ and analyzed in a TOC analyzer (Shimadzu TOC-Vcsh Total Organic Carbon Analyzer, Kyoto, Japan) at the Environmental Analytical Laboratory at University of California, Merced; standards ranged from 0 to $25 \mathrm{mg} \mathrm{L}^{-1}$, with a standard curve $r^{2}=0.999$. Samples for dissolved organic matter (DOM) absorbance were kept in the dark at $4{ }^{\circ} \mathrm{C}$ for no longer than 5 days until analyzed in a Genesys 10 UV spectrophotometer for absorption at 254 
nm (Thermo Scientific; Madison, WI, USA). The specific UV absorbance at $254 \mathrm{~nm}$ (SUVA $254 \mathrm{~nm}$ ) was calculated by dividing measured $254 \mathrm{~nm}$ absorbance per $\mathrm{m}$ of path length values by the DOC concentration of each sample. These $\mathrm{SUVA}_{254 \mathrm{~nm}}$ values have been used as indices of DOC aromaticity (e.g.,Weishaar et al. 2003).

Apparent oxygen utilization (AOU) was calculated from the following equation:

$$
A O U=O_{2, s a t}-O_{2}
$$

where $\mathrm{O}_{2 \text {,sat }}$ is the saturation oxygen concentration dependent on temperature and salinity and $\mathrm{O}_{2}$ is the observed oxygen concentration.

\section{Statistical analyses}

We tested relationships between $\mathrm{CH}_{4}$ concentrations in lake surface water and the following individual environmental variables using linear regression: $\mathrm{T}, \mathrm{DO}, \mathrm{NO}_{2}^{-}$, $\mathrm{NO}_{3}{ }^{-}, \mathrm{NH}_{4}{ }^{+}, \mathrm{PO}_{4}{ }^{3-}$, ratios of dissolved inorganic nitrogen to dissolved inorganic phosphorus (DIN:DIP), DOC, SUVA $254 \mathrm{~nm}$, and elevation. We also used these same variables in standard multiple-linear regression analyses to predict $\mathrm{CH}_{4}$ concentrations. Predictor variables and multi-linear models were selected based upon adjusted $R^{2}$ values, Aikake Information Criteria (AIC) of goodness of fit, and model significance. A priori significance level was defined as $\alpha<0.05$. We ran multi-linear regressions for the pooled data as well as for mid-elevation (Lukens, Upper and Lower Cathedral Lakes) and upper-elevation (Lower and Upper Gaylor Lakes) lakes separately. Data were assessed to ensure they met the assumptions of regression (independence of observations, homoscedasticity, and normality of residuals). Methane concentrations were natural-log-transformed due to non-normality of residuals and heteroscedasticity, but the predictor variables met all linear regression assumptions previously mentioned. 
All statistical analyses were performed using IBM SPSS Statistics for Macintosh, Version 25.0. Graphs were developed with Plotly Technologies Inc. Chart Studio (Cambridge, MA, USA) and SPSS (Chicago, IL, USA).

\section{Results}

\section{Methane concentrations and diffusive fluxes within and across lakes}

Methane concentrations and fluxes in lakes are often measured at single time points, even though they may have a highly dynamic nature. In our study, $\mathrm{CH}_{4}$ concentrations showed large variations across lakes and over time, ranging from 16 to 3679 nM (Fig. 2a). All of these values were supersaturated, indicating that all lakes were net sources of $\mathrm{CH}_{4}$ to the atmosphere at all times (Table 1). Within individual lakes, the highest and most variable $\mathrm{CH}_{4}$ concentrations were found in Lukens and Lower Gaylor Lakes. Lukens is located at the lowest elevation and generally showed the highest $\mathrm{CH}_{4}$ concentrations - although the single highest value was observed in Lower Gaylor, the majority of concentrations $>500 \mathrm{nM}$ occurred in Lukens Lake (Fig. 2a). Methane concentrations were highest in Lukens Lake in August in both years. In 2016, $\mathrm{CH}_{4}$ concentrations showed a clear peak, while in 2017, $\mathrm{CH}_{4}$ ranged from 1000 to1500 nM before declining later in September to a November minimum. Lower Gaylor had highly variable $\mathrm{CH}_{4}$ concentrations in 2017 , with an abnormally high value of $3679 \mathrm{nM}$ in July 2017. Unlike the rest of the lakes, Lower Gaylor $\mathrm{CH}_{4}$ concentrations were also significantly elevated at the end of the sampling season in late September and early October 2017, when temperatures were lowest. However, during 2016, $\mathrm{CH}_{4}$ concentrations and patterns in Lower Gaylor Lake were more similar to the other lakes - values were $<500 \mathrm{nM}$, with the highest values in summer. Methane 
concentrations were typically confined to a narrow range within both Cathedral Lakes, ranging from 132 to $354 \mathrm{nM}$ in Lower Cathedral and from 129 to $356 \mathrm{nM}$ in Upper Cathedral, with the highest concentrations occurring in July through August for both lakes. Upper Gaylor is located at the highest elevation and presented the lowest surface $\mathrm{CH}_{4}$ concentrations, ranging from 16 to $280 \mathrm{nM}$. In both 2016 and 2017, $\mathrm{CH}_{4}$ concentrations were the highest earlier on the sampling season. Similar to the other lakes, $\mathrm{CH}_{4}$ concentrations reached a minimum at the end of the sampling season. All lakes therefore showed significant temporal variation in dissolved $\mathrm{CH}_{4}$ concentrations.

Diffusive $\mathrm{CH}_{4}$ fluxes ranged from 0.007 to $2.3 \mathrm{mmol} \mathrm{m}^{-2}$ day ${ }^{-1}$ (Fig. 2b, Table 1). Lukens Lake exhibited higher diffusive fluxes during 2016 than 2017 (Fig. 2b, Table 1), and diffusive fluxes were generally higher in August through September (with the exception of July 2017), while Cathedral and Upper Gaylor lakes observed fluxes of $>0.2 \mathrm{mmol} \mathrm{m}^{-2}$ day $^{-1}$ during the whole sampling season for both 2016 and 2017. Lower Gaylor diffusive fluxes were low overall in $2016\left(0.03-0.3 \mathrm{mmol} \mathrm{m}^{-2} \mathrm{day}^{-1}\right)$, but higher and more variable in 2017, when we observed the highest diffusive flux in July (2.3 mmol m $\left.\mathrm{m}^{-2} \mathrm{day}^{-1}\right)$ followed by the lowest in August $\left(0.08 \mathrm{mmol} \mathrm{m}^{-2} \mathrm{day}^{-1}\right)$.

\section{Seasonal and elevational variation in methane and temperature}

Along with variation in $\mathrm{CH}_{4}$, temperature showed expected seasonal and elevational variation within and across lakes. We observed similar seasonal trends in all lakes, where peak temperatures occurred in late July and early August, and temperatures were lowest at the end of the sampling season in October through November for both 2016 and 2017 (Fig. 2c). Within individual lakes, Lukens Lake is located at the lowest elevation $(2489 \mathrm{~m})$ and experienced the highest temperatures, ranging from $11.6{ }^{\circ} \mathrm{C}$ to $22.4{ }^{\circ} \mathrm{C}$. At higher elevations, Lower Cathedral reached the highest temperature on July 
2016 at $21.0^{\circ} \mathrm{C}$, and the lowest on October 2017 at $10.9^{\circ} \mathrm{C}$. Upper Cathedral had a similar temperature range $\left(11.6-20.5^{\circ} \mathrm{C}\right)$ and timing of peak values. The two lakes at the highest elevations presented the lowest temperatures at the beginning of the sampling season during ice thaw, and again at the end of sampling season in October, when temperatures declined to $7.9{ }^{\circ} \mathrm{C}$ in Lower Gaylor and $7.7{ }^{\circ} \mathrm{C}$ in Upper Gaylor. Highest temperatures in these lakes occurred in July 2016: $18.8^{\circ} \mathrm{C}$ for Lower Gaylor and 15.5 ${ }^{\circ} \mathrm{C}$ for Upper Gaylor. Temperature seasonal trends were consistent for both 2016 and 2017; these temporal variations emphasize the large temperature range that highelevation lakes display and the effect of elevation on their average temperatures.

Given coincident seasonal variations in $\mathrm{CH}_{4}$ concentrations and temperature, consistent differences between lakes at different elevations, and previous work demonstrating temperature effects on $\mathrm{CH}_{4}$ emissions, we analyzed potential relationships between temperature and $\mathrm{CH}_{4}$ concentrations (Fig. 3a). Within individual lakes, $\mathrm{CH}_{4}$ concentrations correlated with seasonal temperature variations in lake water in Lukens $\left(r^{2}=0.65, p<0.005, \mathrm{n}=12\right)$, Lower Cathedral $\left(r^{2}=0.53, p<0.05, \mathrm{n}=8\right)$ and Upper Cathedral Lake $\left(r^{2}=0.81, p<0.005, \mathrm{n}=8\right)$. Methane concentrations were not significantly related to temperature in Upper Gaylor Lake, and were inversely related to temperature in Lower Gaylor Lake $\left(r^{2}=0.43, p<0.05, \mathrm{n}=11\right)$. Data pooled across all lakes showed no significant correlation between $\mathrm{CH}_{4}$ concentrations and temperature, likely due to the different patterns observed in the individual lakes. In particular, lower elevation lakes with more substantial temperature variation showed stronger correspondence between temperature and $\mathrm{CH}_{4}$. We therefore analyzed relationships with elevation and found that elevation was the most significant factor determining $\mathrm{CH}_{4}$ concentrations in the water-overall, the lower the elevation, the higher the $\mathrm{CH}_{4}$ 
concentration in the lake $\left(r^{2}=0.39, p<0.005, \mathrm{n}=49\right)$. Temporal variations within individual lakes are superimposed on this overall pattern.

\section{Organic matter production and composition}

To examine potential relationships between $\mathrm{CH}_{4}$ concentrations and organic $\mathrm{C}$ dynamics, we measured DOC and SUVA in 2017, and DO in 2016 and 2017. DOC followed an elevational trend (Table 1); Lukens Lake presented the highest DOC values (2.54 - 3.74 $\left.\mathrm{mg} \mathrm{L}^{-1}\right)$, followed by Lower and Upper Cathedral Lakes $\left(1.36-2.78 \mathrm{mg} \mathrm{L}^{-1}\right.$ and $1.65-1.97 \mathrm{mg} \mathrm{L}^{-1}$, respectively), and Lower Gaylor presented the lowest values most of the season $\left(1.29-2.58 \mathrm{mg} \mathrm{L}^{-1}\right)$. We observed a DOC maximum in August and a minimum in October for all lakes in 2017. Higher $\mathrm{CH}_{4}$ concentrations correlated with higher DOC concentrations in lake water for the measurements taken from all lakes $\left(r^{2}\right.$ $=0.30, p<0.05, \mathrm{n}=16$; Supplemental Fig. 2a). Methane concentrations were also significantly correlated with $\operatorname{SUVA}_{254 \mathrm{~nm}}\left(r^{2}=0.23, p<0.05, \mathrm{n}=16\right.$; Supplemental Fig. $2 b)$.

We also measured DO, as it (1) is affected by changes in temperature, (2) can integrate changes in production and consumption of organic matter, and (3) affects the redox favorability of $\mathrm{CH}_{4}$ production and oxidation in sediments and water column. During both 2016 and 2017, DO increased over the summer and fall with the lowest values in July and the highest in October (Fig. 4a). Dissolved oxygen ranged from 6.0 to $8.0 \mathrm{mg}$ $\mathrm{L}^{-1}$ in Lukens Lake, 6.0 to $7.8 \mathrm{mg} \mathrm{L}^{-1}$ in Lower Cathedral Lake, and 5.0 to $7.7 \mathrm{mg} \mathrm{L}^{-1}$ in Upper Cathedral Lake. Gaylor Lakes, located at the highest elevation, presented the highest DO, with Lower Gaylor ranging from 5.0 to $8.7 \mathrm{mg} \mathrm{L}^{-1}$ and Upper Gaylor ranging from 6.0 to $8.9 \mathrm{mg} \mathrm{L}^{-1}$. Methane concentrations were inversely correlated with 
DO in Lukens Lake $\left(r^{2}=0.69, p<0.005, \mathrm{n}=11\right)$, while correlations for the other lakes individually or using pooled data across all five lakes were not significant. Given that variations in temperature likely affect observed DO concentrations, we calculated apparent oxygen utilization (AOU) from the difference between DO values expected in equilibrium with the atmosphere at different temperatures versus those observed. Apparent oxygen utilization showed consistent seasonal trends in most of the lakes (Figure $4 \mathrm{~b}$ ). However, $\mathrm{CH}_{4}$ concentrations were not significantly related to AOU.

\section{Inorganic nutrients dynamics}

We measured three forms of dissolved inorganic nitrogen (DIN; ammonium, nitrite, and nitrate), as well as dissolved inorganic phosphorus (DIP; phosphate). High-elevation lakes are typically nutrient depleted (Sickman et al. 2003; Moser et al. 2019), and the lakes in this study are no exception, with low concentrations of all measured inorganic nutrients (Fig. 5).

Ammonium concentrations were low and variable $(0.18$ to $2.83 \mu \mathrm{M}$, with the majority of $\mathrm{NH}_{4}{ }^{+}$concentrations $<1.5 \mu \mathrm{M}$ ), but in contrast to $\mathrm{CH}_{4}, \mathrm{NH}_{4}{ }^{+}$concentrations did not display a seasonal trend and $\mathrm{CH}_{4}$ was not significantly related to $\mathrm{NH}_{4}^{+}$(Fig. 5a). Both $\mathrm{NO}_{2}{ }^{-}$and $\mathrm{NO}_{3}{ }^{-}$concentrations were also low over the period studied, typically ranging from 0 to $1 \mu \mathrm{M}$ (Fig. 5b and 5c). Nitrite trends in the lakes differed from year to year. In 2016, overall variation was higher, and there were no discernible seasonal trends; in 2017, all $\mathrm{NO}_{2}{ }^{-}$concentrations were uniformly $<0.3 \mu \mathrm{M}$, and we observed a seasonal trend for Lukens, Lower and Upper Cathedral Lakes. Methane concentrations were statistically significantly correlated to $\mathrm{NO}_{2}{ }^{-}$in lake water in Lukens $\left(r^{2}=0.41 p<0.05, \mathrm{n}\right.$ $=12)$ and Upper Cathedral $\left(r^{2}=0.52, p<0.05, \mathrm{n}=8\right)$. Methane concentrations in Lower 
and Upper Cathedral Lakes were also significantly related to $\mathrm{NO}_{3}{ }^{-}$in the water $\left(r^{2}=\right.$ 0.64, $p<0.05, \mathrm{n}=7$ for Lower Cathedral and $r^{2}=0.67, p<0.05, \mathrm{n}=8$ for Upper Cathedral). For both $\mathrm{NO}_{2}^{-}$and $\mathrm{NO}_{3}^{-}$, there were no other significant relationships for individual lakes or the pooled lake data. Phosphate concentrations remained below 0.8 $\mu \mathrm{M}$ in these oligotrophic mountain lakes (Fig. 5d). Phosphate concentrations were more variable in $2016(0.1$ to $0.8 \mu \mathrm{M})$ compared to $2017(0.0$ to $0.2 \mu \mathrm{M})$, especially for Lukens and Lower and Upper Gaylor Lakes. However, none of the lakes showed discernible seasonal trends over the summer (although $\mathrm{PO}_{4}{ }^{3-}$ tended to be lowest at the end of the sampling season in October), and $\mathrm{CH}_{4}$ was not significantly related to $\mathrm{PO}_{4}{ }^{3-}$.

The DIN:DIP ratios were typically low, ranging from 3 to 18 for 2016 and 2 to 25 in 2017 (Fig. 5e). Low DIN:DIP ratios indicate that the lakes studied are mainly N limited (DIN:DIP < 10), with fewer cases of DIN:DIP ratios indicative of co-limitation (10 17), or P limitation (DIN:DIP > 17; Morris and Lewis 1988; Nürnberg and Shaw 1998). Upper Cathedral $\mathrm{CH}_{4}$ concentrations showed a negative correlation with DIN:DIP ratio $\left(r^{2}=0.64, p<0.05, \mathrm{n}=8\right)$, while the other lakes individually and overall nutrient dataset were not significantly related to $\mathrm{CH}_{4}$ concentrations.

\section{Multi-linear model for $\mathrm{CH}_{4}$ concentrations in high-elevation lakes}

Given the seasonal and elevation-related patterns observed in high elevation lakes, we tested for statistically significant relationships between $\mathrm{CH}_{4}$ and potential explanatory variables using multiple linear regression. Pooling all lakes together showed that the only significant predictor variable across all lakes was elevation (Table 2); however, individual lakes displayed strong temperature responses, especially at lower elevations. As a result, we classified lakes into two elevational bands (mid- and upper elevation) to 
better understand relationships at different elevations (Table 2). The multilinear regression in the mid-elevation band showed that $\mathrm{CH}_{4}$ concentrations in lake water were significantly correlated to temperature, elevation, and $\mathrm{NO}_{2}^{-}$; in the upper-elevation lake band, $\mathrm{CH}_{4}$ concentrations were significantly related to elevation and DIN:DIP ratios. Methane concentration in individual lake surface water and in the pooled lake data was consistently related to elevation, as well as in the elevation band regressions. Contrary to our hypothesis, $\mathrm{CH}_{4}$ concentrations in mid-elevation lakes, but not upper-elevation lakes, were positively correlated to temperature over the growing season.

\section{Discussion}

\section{Seasonal variation in methane}

Our findings have multiple implications for our understanding of $\mathrm{CH}_{4}$ biogeochemistry in freshwater ecosystems. First and most fundamentally, significant seasonal variability was clearly evident in $\mathrm{CH}_{4}$ concentrations in Sierra Nevada lakes, as highest $\mathrm{CH}_{4}$ concentrations were observed in the warmest months, and lowest $\mathrm{CH}_{4}$ concentrations were typically observed at the end of the sampling season before winter. Field site accessibility prevented taking measurements during the winter and spring seasons, but Greene et al. (2014) and Jammet et al. (2015) showed that there can be significant $\mathrm{CH}_{4}$ release during ice-off due to the build-up of $\mathrm{CH}_{4}$ under ice throughout winter and spring. While this phenomenon was not captured here and could be significant, it underlines our over-arching finding that dissolved $\mathrm{CH}_{4}$ can be highly variable over time.

Second, our data indicate that single time point measurements of $\mathrm{CH}_{4}$ concentrations in lakes do not adequately reflect overall seasonal $\mathrm{CH}_{4}$ diffusive flux, as $\mathrm{CH}_{4}$ 
concentrations varied 3- to 73-fold over time in our study. Previous seasonal $\mathrm{CH}_{4}$ measurements have been conducted in only a handful of lakes worldwide and also show significant variation. For example, Casper et al. (2009) observed a seasonal cycle in a single lake in Germany, where $\mathrm{CH}_{4}$ lake concentrations and fluxes increased in the summer and decreased by winter. Similarly, Palma-Silva et al. (2013) detected higher $\mathrm{CH}_{4}$ concentrations in one oligotrophic and one eutrophic lake in Brazil when higher temperatures were observed — a finding shared for a single shallow pond in Sweden (Natchimuthu et al. 2014), and for a single subtropical lake in China (Xing et al. 2005). Contrarily, Martinez-Cruz et al. (2015) found the opposite pattern for thirty Alaskan Lakes, where $\mathrm{CH}_{4}$ concentrations were on average lower during the summer and higher during the wintertime due to changes in lake ice cover. Taken together, these limited data indicate that seasonal $\mathrm{CH}_{4}$ variations can be significant, and our results provide additional context from five contrasting, high-elevation lakes in the Sierra Nevada.

Third, changes in the length of the growing season will likely increase overall $\mathrm{CH}_{4}$ diffusive flux if periods of high $\mathrm{CH}_{4}$ concentrations in lake water expand in time. This may be especially relevant for high-elevation lakes, where warmer air temperatures will increase the lake ice-free period, increase water temperature, and potentially increase organic matter and nutrient inputs from the surrounding watershed — at least in the short-term (Moser et al. 2019; Sadro et al. 2019). In line with this idea, our results showed that $\mathrm{CH}_{4}$ concentrations in high-elevation lakes were most strongly correlated with elevation, with higher average $\mathrm{CH}_{4}$ concentrations at lower elevations. Elevation can be a proxy for temperature, as lower elevations showed the lowest mean temperatures (see below). If high-elevation lakes shift to resemble lower-elevation lakes, the strong correlation with elevation suggests increased $\mathrm{CH}_{4}$ concentrations. 
However, both organic $\mathrm{C}$ concentrations and composition, as well as nutrient concentrations, may also vary with elevation. In general, lakes at higher elevation tend to be more oligotrophic, as allochthonous sources of $\mathrm{C}$ and nutrients become more scarce in alpine and sub-alpine regions (Urmy and Warren 2019). We therefore evaluated organic matter and nutrients as potentially relevant factors for $\mathrm{CH}_{4}$ cycling in lakes that are also elevation dependent.

\section{Relationships between methane, organic matter production and} composition, and dissolved nutrients

The quality and quantity of organic matter can affect methanogenesis in lakes because organic matter provides substrates for $\mathrm{CH}_{4}$ production, and affects oxygen availability in sediments due to heterotrophic aerobic respiration (Tranvik et al. 2009; Grasset et al. 2018; Sepulveda-Jauregui et al. 2018). We found that patterns in DOC and SUVA254nm were consistent with lake elevation and watershed characteristics (Table 1). In particular, Lukens Lake is located at the lowest elevation with a surrounding meadow, and likely has a larger input of allochthonous $\mathrm{C}$, while Lower and Upper Cathedral Lakes are at higher elevation where allochthonous $\mathrm{C}$ would be relatively lower. Lower and Upper Gaylor Lakes are located above the tree line where DOC levels tend to be lower (Moser et al. 2019). Consistent with this, DOC concentrations were the highest at the lowest elevation and decreased with increases in elevation (Table 1). The specific $\mathrm{UV}$ absorbance at $254 \mathrm{~nm}$ is a useful measure to perceive changes in organic $\mathrm{C}$ over the growing season. Low $\mathrm{SUVA}_{254 \mathrm{~nm}}$ is indicative of overall low molecular weight (Chowdhury 2013) and low percent aromaticity (Weishaar et al. 2003). Allochthonous sources of organic $\mathrm{C}$ are often complex molecules (aliphatic polymers, humic substances) that are mainly degraded under aerobic conditions, whereas autochthonous 
sources can be mineralized under both aerobic and anaerobic conditions (Zehnder and Svensson 1986; Hulthe et al. 1998; Bastviken et al. 2004). In our study, the inverse correlation between $\mathrm{CH}_{4}$ concentrations and $\mathrm{SUVA}_{254 \mathrm{~nm}}$ values (Supplemental Fig. 2) suggests that simple $\mathrm{C}$ molecules favor enhanced $\mathrm{CH}_{4}$ production.

High-elevation lakes are also often oligotrophic, such that changes in nutrient concentrations can affect the overall ecology of the lake. Higher nutrient input to lakes can alter lake community structure and enhance primary productivity and $\mathrm{CH}_{4}$ production (Tranvik et al. 2009; West et al. 2016; Reay et al. 2018). Overall, we found low concentrations of all dissolved inorganic nutrients - consistent with oligotrophic conditions prevalent in high-elevation lakes. Although both nitrogen $(\mathrm{N})$ and phosphorus (P) may be limiting nutrients in freshwater ecosystems (Elser et al. 2007), $\mathrm{P}$ availability is particularly relevant to the $\mathrm{CH}_{4}$ paradox (i.e., the observation of consistent supersaturation of $\mathrm{CH}_{4}$ in freshwater and marine oxic surface waters; Karl et al. 2008; Tang et al. 2014). Several studies have proposed that biological mechanisms other than traditional methanogenesis produce $\mathrm{CH}_{4}$ (Grossart et al. 2011; Bogard et al. 2014; Tang et al. 2016; Bižić et al. 2020) and one mechanism that may be particularly important in oligotrophic ecosystems is the demethylation of methyl phosphonate. This can be performed by multiple groups of bacteria using C-P lyase genes during the degradation of DOM (Repeta et al. 2016; Yao et al. 2016; Wang et al. 2017), and has been observed in both freshwater (Yao et al. 2016; Wang et al. 2017) and marine (Karl et al. 2008; Metcalf et al. 2012; Carini et al. 2014; Repeta et al. 2016) ecosystems.

In our study, we found low but detectable $\mathrm{PO}_{4}{ }^{3-}$ concentrations through most of the icefree season in most lakes. This result is consistent with a long-term study of Emerald 
Lake in the Sierra Nevada (Sickman et al. 2003). We focused on inorganic nutrient concentrations because previous work has shown that ecological changes associated with nutrient enrichment can affect $\mathrm{CH}_{4}$ fluxes, and changes in bioavailable $\mathrm{P}$ could affect $\mathrm{CH}_{4}$ production via methyl phosphonate breakdown. In particular, we might expect that low $\mathrm{P}$ availability overall, or in comparison to $\mathrm{N}$, might result in increased microbial methylphosphonate breakdown, and therefore increased $\mathrm{CH}_{4}$ production. However, we did not observe significant relationships between $\mathrm{CH}_{4}$ concentrations and DIP.

Instead, $\mathrm{CH}_{4}$ was related to dissolved nitrite, nitrate, and DIN:DIP ratios within some individual lakes and in multiple linear regression (Supplemental Fig. 1, Table 2). While $\mathrm{CH}_{4}$ concentrations were not as consistently related to inorganic nutrients as they were to temperature and elevation, they still displayed significant correlations in some of the high-elevations lakes studied here (Supplemental Fig. 1). Higher elevation lakes exhibit lower nutrient and DOC concentrations than mid-elevations lakes (Moser et al. 2019; Urmy and Warren 2019); in this area, microbial activities may be constrained by nutrient concentrations. Previous studies have found that alpine ecosystems are highly sensitive to modest $\mathrm{N}$ deposition (Baron et al. 2000; Wolfe et al. 2003; Vinebrooke et al. 2014). Consistently, lakes in this study were likely N-depleted for the majority of the season, which may explain why $\mathrm{CH}_{4}$ concentrations were predicted to be higher when $\mathrm{N}$ was more available either in the $\mathrm{NO}_{2}^{-}$form or as a higher DIN:DIP ratio.

\section{Methane dynamics in relation to elevation and temperature}

We found significant relationships between $\mathrm{CH}_{4}$ concentrations and elevation and temperature. Highest $\mathrm{CH}_{4}$ concentrations were observed at the lowest elevation lake and 
decreased with elevation. While associated with elevation, temperature was also correlated with $\mathrm{CH}_{4}$ concentrations measured over time in the mid-elevation lakes ( $<3000$ m, Lukens, Upper and Lower Cathedral Lakes). In our study, lakes located at different elevations with different mean temperatures showed distinct seasonal patterns in temperature and $\mathrm{CH}_{4}$ concentrations. Likewise, lakes sampled in earlier work also varied in the strength of $\mathrm{CH}_{4}$-temperature relationships (Xing et al. 2005; Casper et al. 2009; Palma-Silva et al. 2013; Natchimuthu et al. 2014), but showed that temperature increases have overall a corresponding positive response on lake $\mathrm{CH}_{4}$ concentrations (Natchimuthu et al. 2014; Marotta et al. 2014; Yvon-Durocher et al. 2014; Rasilo et al. 2015). Our data provide additional evidence of positive temperature- $\mathrm{CH}_{4}$ relationships in several lakes.

Collectively, these observations lend support to the hypothesis that $\mathrm{CH}_{4}$ concentrations are typically closely related to temperature, but other factors that vary seasonally or with elevation may also be important in regulating $\mathrm{CH}_{4}$ concentrations in lakes. In particular, $\mathrm{CH}_{4}$ concentrations were correlated with temperature, elevation, and $\mathrm{NO}_{2}^{-}$in mid-elevation lakes. In contrast, the lack of a temperature response in the upperelevation lakes indicates that $\mathrm{CH}_{4}$ concentrations may be affected by other factors. For example, nutrient availability regulates lake productivity, and nutrient increases have been correlated with enhanced $\mathrm{CH}_{4}$ emissions (Palma-Silva et al. 2013; West et al. 2016). Disentangling the relative influence of temperature, nutrients, and $\mathrm{C}$ in high elevation lakes may be achieved through additional experimental work, as our measurements indicate that all of these factors can be significantly related to $\mathrm{CH}_{4}$ concentrations. 
Methane ebullitive fluxes were not measured in this study but can be a major contribution to total lake $\mathrm{CH}_{4}$ emissions, especially in shallow lakes (Bastviken et al. 2004; DelSontro et al. 2016). Lake $\mathrm{CH}_{4}$ ebullitive emissions have been found to be significantly sensitive to increases in temperature and changes in nutrient concentrations (DelSontro et al. 2016; Aben et al. 2017; Davidson et al. 2018) and deserve further research. Combining these data from five Sierran lakes with additional observations (including ebullitive fluxes) from other temperate montane lakes may result in the development of robust, multivariate predictive models to accurately predict $\mathrm{CH}_{4}$ concentrations and emissions over space and time as the climate continues to warm. Concentrations of $\mathrm{CH}_{4}$ in high elevation lakes are notably high and variable, and are indicative of dynamic $\mathrm{CH}_{4}$ cycling. Our study provides additional fundamental information on freshwater $\mathrm{CH}_{4}$ biogeochemistry in montane lakes; these data should be useful in the development of predictive models of $\mathrm{CH}_{4}$ fluxes from freshwater ecosystems under this current period of rapid global change. 


\section{Acknowledgments}

This work was supported by the University of California through the Valentine Eastern Sierra Reserve graduate student research grant, the Institute for the Study of Ecological and Evolutionary Climate Impacts fellowship, and the University of California Merced Environmental Systems summer grants. We thank the USA National Park Service for facilitating sample collection in Yosemite National Park under permits YOSE-2016SCI-0118 and YOSE-2017-SCI-0104. We thank Angela Yu, Ariadna Cairo, Daniela Alonso, Jesse Wilson, Joaquin Fraga, Jorge Montiel and Sonia Vargas of the Beman Lab for helping with field work and sample processing. We thank Adam Cohen, Didra Felix, Hamanda Cavalheri, Jennifer Leong and Natalie Jones for field assistance and scientific advice. We also thank Carol Blanchette and the Sierra Nevada Aquatic Research Laboratory staff for facilitating field and laboratory work in the Eastern Sierra Nevada. 


\section{References}

Aben RCH, Barros N, van Donk E, Frenken T, Hilt S, Kazanjian G, Lamers LPM, Peeters ETHM, Roelofs JGM, de Senerpont Domis LN, et al. 2017. Cross continental increase in methane ebullition under climate change. Nat. Commun 8(1):1-8.

Aciego SM, Riebe CS, Hart SC, Blakowski MA, Carey CJ, Aarons SM, Dove NC, Botthoff JK, Sims KWW, Aronson EL. 2017. Dust outpaces bedrock in nutrient supply to montane forest ecosystems. Nat. Commun 8:14800.

Amorocho J, DeVries JJ. 1980. A new evaluation of the wind stress coefficient over water surfaces. J. Geophys. Res. Oceans. 85(C1):433-442.

APHA. 1998. Nitrogen (Nitrite) (4500- $\left.\mathrm{NO}_{2}{ }^{-}\right) /$Colorimetric method. In: American Public Health Association, American Water Works Association and Water Environmental Federation, editors. Standard methods for the examination of water and wastewater. 18th edn. Washington DC. p. 4-85 - 4-87.

Baron JS, Rueth HM, Wolfe AM, Nydick KR, Allstott EJ, Minear JT, Moraska B. 2000. Ecosystem Responses to Nitrogen Deposition in the Colorado Front Range. Ecosystems. 3(4):352-368.

Bartosiewicz M, Laurion I, MacIntyre S. 2015. Greenhouse gas emission and storage in a small shallow lake. Hydrobiologia. 757(1):101-115.

Bastviken D, Cole J, Pace M, Tranvik L. 2004. Methane emissions from lakes: Dependence of lake characteristics, two regional assessments, and a global estimate. Global Biogeochem Cycles. 18(4).

Bastviken D, Tranvik LJ, Downing JA, Crill PM, Enrich-Prast A. 2011. Freshwater Methane Emissions Offset the Continental Carbon Sink. Science. 331(6013):50-50.

Bižić M, Klintzsch T, Ionescu D, Hindiyeh MY, Günthel M, Muro-Pastor AM, Eckert W, Urich T, Keppler F, Grossart H-P. 2020. Aquatic and terrestrial cyanobacteria produce methane. Sci. Adv. 6(3).

Bogard MJ, del Giorgio PA, Boutet L, Chaves MCG, Prairie YT, Merante A, Derry AM. 2014. Oxic water column methanogenesis as a major component of aquatic $\mathrm{CH}_{4}$ fluxes. Nat. Commun 5:5350.

Carini P, White AE, Campbell EO, Giovannoni SJ. 2014. Methane production by phosphate-starved SAR11 chemoheterotrophic marine bacteria. Nat. Commun 5:4346.

Casper P, Albino MF, Adams DD. 2009. Diffusive fluxes of CH4 and CO2 across the water-air interface in the eutrophic Lake Dagow, northeast Germany. SIL Proceedings, 1922-2010. 30(6):874-877.

Chapman P, Mostert SA. 1990. Does freezing of nutrient samples cause analytical errors? South African Journal of Marine Science. 9(1):239-247. 
Chowdhury S. 2013. Trihalomethanes in drinking water: Effect of natural organic matter distribution. Water SA. 39(1):1-8-8.

Cole JJ, Caraco NF. 1998. Atmospheric exchange of carbon dioxide in a low-wind oligotrophic lake measured by the addition of SF6. Limnol. Oceanogr. 43(4):647-656.

Conrad R. 1999. Contribution of hydrogen to methane production and control of hydrogen concentrations in methanogenic soils and sediments. FEMS Microbiol Ecol. 28(3):193-202.

Conrad R. 2009. The global methane cycle: recent advances in understanding the microbial processes involved. Environ. Microbiol. Rep. 1(5):285-292.

Davidson TA, Audet J, Jeppesen E, Landkildehus F, Lauridsen TL, Søndergaard M, Syväranta J. 2018. Synergy between nutrients and warming enhances methane ebullition from experimental lakes. Nat. Clim. Change. 8(2):156.

DelSontro T, Beaulieu JJ, Downing JA. 2018. Greenhouse gas emissions from lakes and impoundments: Upscaling in the face of global change. Limnol. Oceanogr Letters. 3(3):64-75.

DelSontro T, Boutet L, St-Pierre A, del Giorgio PA, Prairie YT. 2016. Methane ebullition and diffusion from northern ponds and lakes regulated by the interaction between temperature and system productivity. Limnol. Oceanogr. 61(S1):S62-S77.

Downing JA. 2009. Global limnology: up-scaling aquatic services and processes to planet Earth. SIL Proceedings, 1922-2010. 30(8):1149-1166.

Duc NT, Crill P, Bastviken D. 2010. Implications of temperature and sediment characteristics on methane formation and oxidation in lake sediments. Biogeochemistry. 100(1):185-196.

Elser JJ, Bracken MES, Cleland EE, Gruner DS, Harpole WS, Hillebrand H, Ngai JT, Seabloom EW, Shurin JB, Smith JE. 2007. Global analysis of nitrogen and phosphorus limitation of primary producers in freshwater, marine and terrestrial ecosystems. Ecol. Lett. 10(12):1135-1142.

Elser JJ, Kyle M, Steger L, Nydick KR, Baron JS. 2009. Nutrient availability and phytoplankton nutrient limitation across a gradient of atmospheric nitrogen deposition. Ecology. 90(11):3062-3073.

Grasset C, Mendonça R, Saucedo GV, Bastviken D, Roland F, Sobek S. 2018. Large but variable methane production in anoxic freshwater sediment upon addition of allochthonous and autochthonous organic matter. Limnol. Oceanogr. 63(4):1488-1501.

Greene S, Walter Anthony KM, Archer D, Sepulveda-Jauregui A, Martinez-Cruz K. 2014. Modeling the impediment of methane ebullition bubbles by seasonal lake ice. Biogeosciences. 11(23):6791-6811.

Grossart H-P, Frindte K, Dziallas C, Eckert W, Tang KW. 2011. Microbial methane production in oxygenated water column of an oligotrophic lake. PNAS. 108(49):1965719661. 
Harrits SM, Hanson RS. 1980. Stratification of aerobic methane-oxidizing organisms in Lake Mendota, Madison, Wisconsin1. Limnol. Oceanogr. 25(3):412-421.

Hayden CJ, Beman JM. 2016. Microbial diversity and community structure along a lake elevation gradient in Yosemite National Park, California, USA. Environ. Microbiol. 18(6):1782-1791.

Holmes RM, Aminot A, Kérouel R, Hooker BA, Peterson BJ. 1999. A simple and precise method for measuring ammonium in marine and freshwater ecosystems. Can $\mathrm{J}$ Fish Aquat Sci. 56(10):1801-1808.

Hoegh-Guldberg O, Jacob D, Taylor M, Bindi M, et al. 2018. Impacts of $1.5^{\circ} \mathrm{C}$ Global Warming on Natural and Human Systems. In: MassonDelmotte V, Zhai P, Pörtner HO, Roberts D, Skea J, Shukla PR, Pirani A, Moufouma-Okia W, Péan C, Pidcock R, Connors S, Matthews JBR, Chen Y, Zhou X, Gomis MI, Lonnoy E, Maycock T, Tignor $\mathrm{M}$, Waterfield T, editors. Global Warming of $1.5^{\circ} \mathrm{C}$. An IPCC Special Report on the Impacts of Global Warming of $1.5^{\circ} \mathrm{C}$ above Pre-Industrial Levels and Related Global Greenhouse Gas Emission Pathways, in the Context of Strengthening the Global Response to the Threat of Climate Change, Sustainable Development, and Efforts to Eradicate Poverty.

Hulthe G, Hulth S, Hall POJ. 1998. Effect of oxygen on degradation rate of refractory and labile organic matter in continental margin sediments. Geochim. Cosmochim. Acta. 62(8):1319-1328.

Jammet M, Crill P, Dengel S, Friborg T. 2015. Large methane emissions from a subarctic lake during spring thaw: Mechanisms and landscape significance. Journal of Geophysical Research: Biogeosciences. 120(11):2289-2305.

Karl DM, Beversdorf L, Björkman KM, Church MJ, Martinez A, Delong EF. 2008. Aerobic production of methane in the sea. Nat. Geosci. 1(7):473-478.

Kirschke S, Bousquet P, Ciais P, Saunois M, Canadell JG, Dlugokencky EJ, Bergamaschi P, Bergmann D, Blake DR, Bruhwiler L, et al. 2013. Three decades of global methane sources and sinks. Nat. Geosci. 6(10):813-823.

Liikanen A, Huttunen JT, Valli K, Martikainen PJ. 2002. Methane cycling in the sediment and water column of mid-boreal hyper-eutrophic Lake Kevätön, Finland. Arch. Hydrobiol.:585-603.

Lofton DD, Whalen SC, Hershey AE. 2014. Effect of temperature on methane dynamics and evaluation of methane oxidation kinetics in shallow Arctic Alaskan lakes. Hydrobiologia. 721(1):209-222.

Marotta H, Pinho L, Gudasz C, Bastviken D, Tranvik LJ, Enrich-Prast A. 2014. Greenhouse gas production in low-latitude lake sediments responds strongly to warming. Nat. Clim. Change. 4(6):467-470.

Martinez-Cruz K, Sepulveda-Jauregui A, Walter Anthony K, Thalasso F. 2015. Geographic and seasonal variation of dissolved methane and aerobic methane oxidation in Alaskan lakes. Biogeosciences. 12(15):4595-4606. 
McCrackin ML, Elser JJ. 2011. Greenhouse gas dynamics in lakes receiving atmospheric nitrogen deposition. Global Biogeochem Cycles. 25(4).

Melack JM, Stoddard JL. 1991. Sierra Nevada, California. In: Charles DF, editor. Acidic Deposition and Aquatic Ecosystems: Regional Case Studies [Internet]. New York, NY: Springer New York; [accessed 2019 Feb 5]; p. 503-530.

Metcalf WW, Griffin BM, Cicchillo RM, Gao J, Janga SC, Cooke HA, Circello BT, Evans BS, Martens-Habbena W, Stahl DA, Donk WA van der. 2012. Synthesis of Methylphosphonic Acid by Marine Microbes: A Source for Methane in the Aerobic Ocean. Science. 337(6098):1104-1107.

Morris DP, LEWIS Jr WM. 1988. Phytoplankton nutrient limitation in Colorado mountain lakes. Freshw. Biol. 20(3):315-327.

Moser KA, Baron JS, Brahney J, Oleksy IA, Saros JE, Hundey EJ, Sadro SA, Kopáček J, Sommaruga R, Kainz MJ, et al. 2019. Mountain lakes: Eyes on global environmental change. Glob Planet Change. 178:77-95

Mountain Research Initiative EDW Working Group, Pepin N, Bradley RS, Diaz HF, Baraer M, Caceres EB, Forsythe N, Fowler H, Greenwood G, Hashmi MZ, et al. 2015. Elevation-dependent warming in mountain regions of the world. Nat. Clim. Change. 5(5):424-430.

Natchimuthu S, Panneer Selvam B, Bastviken D. 2014. Influence of weather variables on methane and carbon dioxide flux from a shallow pond. Biogeochemistry. 119(1):403-413.

Nürnberg GK, Shaw M. 1998. Productivity of clear and humic lakes: nutrients, phytoplankton, bacteria. Hydrobiologia. 382(1):97-112.

O'Reilly CM, Sharma S, Gray DK, Hampton SE, Read JS, Rowley RJ, Schneider P, Lenters JD, McIntyre PB, Kraemer BM, et al. 2015. Rapid and highly variable warming of lake surface waters around the globe. Geophys. Res. Lett. 42(24):10,773-10,781.

Palma-Silva C, Marinho CC, Albertoni EF, Giacomini IB, Figueiredo Barros MP, Furlanetto LM, Trindade CRT, Esteves F de A. 2013. Methane emissions in two small shallow neotropical lakes: The role of temperature and trophic level. Atmos. Environ. 81:373-379.

Rasilo T, Prairie YT, Giorgio PA del. 2015. Large-scale patterns in summer diffusive CH4 fluxes across boreal lakes, and contribution to diffusive $\mathrm{C}$ emissions. Glob. Change. Biol. 21(3):1124-1139.

Reay DS, Smith P, Christensen TR, James RH, Clark H. 2018. Methane and Global Environmental Change. Annu. Rev. Env. Resour. 43(1):165-192.

Repeta DJ, Ferrón S, Sosa OA, Johnson CG, Repeta LD, Acker M, DeLong EF, Karl DM. 2016. Marine methane paradox explained by bacterial degradation of dissolved organic matter. Nat. Geosci. 9(12):884-887. 
Sadro S, Melack JM, Sickman JO, Skeen K. 2019. Climate warming response of mountain lakes affected by variations in snow. Limnol. Oceanogr Letters. 4(1):9-17.

Saunois M, Bousquet P, Poulter B, Peregon A, Ciais P, Canadell JG, Dlugokencky EJ, Etiope G, Bastviken D, Houweling S, et al. 2016. The global methane budget 20002012. Earth Syst. Sci. Data. 8(2).

Sepulveda-Jauregui A, Hoyos-Santillan J, Martinez-Cruz K, Walter Anthony KM, Casper P, Belmonte-Izquierdo Y, Thalasso F. 2018. Eutrophication exacerbates the impact of climate warming on lake methane emission. Science of The Total Environment. 636:411-419.

Sickman JO, Melack JM, Clow DW. 2003. Evidence for nutrient enrichment of highelevation lakes in the Sierra Nevada, California. Limnol. Oceanogr. 48(5):1885-1892.

Sun F, Berg N, Hall A, Schwartz M, Walton D. 2019. Understanding End-of-Century Snowpack Changes Over California’s Sierra Nevada. Geophys. Res. Lett. 46(2):933943.

Tang KW, McGinnis DF, Frindte K, Brüchert V, Grossart H-P. 2014. Paradox reconsidered: Methane oversaturation in well-oxygenated lake waters. Limnol. Oceanogr. 59(1):275-284.

Tang KW, McGinnis DF, Ionescu D, Grossart H-P. 2016. Methane Production in Oxic Lake Waters Potentially Increases Aquatic Methane Flux to Air. Environ Sci Technol Lett. 3(6):227-233.

Tranvik LJ, Downing JA, Cotner JB, Loiselle SA, Striegl RG, Ballatore TJ, Dillon P, Finlay K, Fortino K, Knoll LB, et al. 2009. Lakes and reservoirs as regulators of carbon cycling and climate. Limnol. Oceanogr. 54(6part2):2298-2314.

Urmy SS, Warren JD. 2019. Seasonal changes in the biomass, distribution, and patchiness of zooplankton and fish in four lakes in the Sierra Nevada, California. Freshw. Biol. 64(10):1692-1709.

Verpoorter C, Kutser T, Seekell DA, Tranvik LJ. 2014. A global inventory of lakes based on high-resolution satellite imagery. Geophys. Res. Lett. 41(18):6396-6402.

Vinebrooke RD, Maclennan MM, Bartrons M, Zettel JP. 2014. Missing effects of anthropogenic nutrient deposition on sentinel alpine ecosystems. Glob Change Biol. 20(7):2173-2182.

Walton DB, Hall A, Berg N, Schwartz M, Sun F. 2016. Incorporating Snow Albedo Feedback into Downscaled Temperature and Snow Cover Projections for California's Sierra Nevada. J Climate. 30(4):1417-1438.

Wang Q, Dore JE, McDermott TR. 2017. Methylphosphonate metabolism by Pseudomonas sp. populations contributes to the methane oversaturation paradox in an oxic freshwater lake. Environ. Microbiol. 19(6):2366-2378.

Wanninkhof R. 2014. Relationship between wind speed and gas exchange over the ocean revisited. Limnol. Oceanogr: Methods. 12(6):351-362. 
Weishaar JL, Aiken GR, Bergamaschi BA, Fram MS, Fujii R, Mopper K. 2003. Evaluation of Specific Ultraviolet Absorbance as an Indicator of the Chemical Composition and Reactivity of Dissolved Organic Carbon. Environ Sci Technol. 37(20):4702-4708.

Weiss RF. 1981. Determinations of Carbon Dioxide and Methane by Dual Catalyst Flame Ionization Chromatography and Nitrous Oxide by Electron Capture Chromatography. J Chromatogr Sci. 19(12):611-616.

West WE, Creamer KP, Jones SE. 2016. Productivity and depth regulate lake contributions to atmospheric methane. Limnol. Oceanogr. 61(S1):S51-S61.

Williams MW, Hood E, Caine N. 2001. Role of organic nitrogen in the nitrogen cycle of a high-elevation catchment, Colorado Front Range. Water Resour. Res. 37(10):25692581.

Wolfe AP, Gorp ACV, Baron JS. 2003. Recent ecological and biogeochemical changes in alpine lakes of Rocky Mountain National Park (Colorado, USA): a response to anthropogenic nitrogen deposition. Geobiology. 1(2):153-168.

Xing Y, Xie P, Yang H, Ni L, Wang Y, Rong K. 2005. Methane and carbon dioxide fluxes from a shallow hypereutrophic subtropical Lake in China. Atmos. Environ. 39(30):5532-5540.

Yamamoto S, Alcauskas JB, Crozier TE. 1976. Solubility of methane in distilled water and seawater. J Chem Eng Data. 21(1):78-80.

Yao M, Henny C, Maresca JA. 2016. Freshwater Bacteria Release Methane as a ByProduct of Phosphorus Acquisition. Appl Environ Microbiol. 82(23):6994-7003.

Yvon-Durocher G, Allen AP, Bastviken D, Conrad R, Gudasz C, St-Pierre A, ThanhDuc N, del Giorgio PA. 2014. Methane fluxes show consistent temperature dependence across microbial to ecosystem scales. Nature. 507(7493):488-491.

Zehnder AJB, Svensson BH. 1986. Life without oxygen: what can and what cannot? Experientia. 42(11):1197-1205.

Zeikus JG, Winfrey MR. 1976. Temperature limitation of methanogenesis in aquatic sediments. Appl Environ Microbiol. 31(1):99-107. 


\section{Tables and figures}

Table 1. Summary of descriptive statistics of environmental parameters measured from early July to late October 2016 and 2017 for five temperate montane lakes in the Sierra Nevada, California, USA.

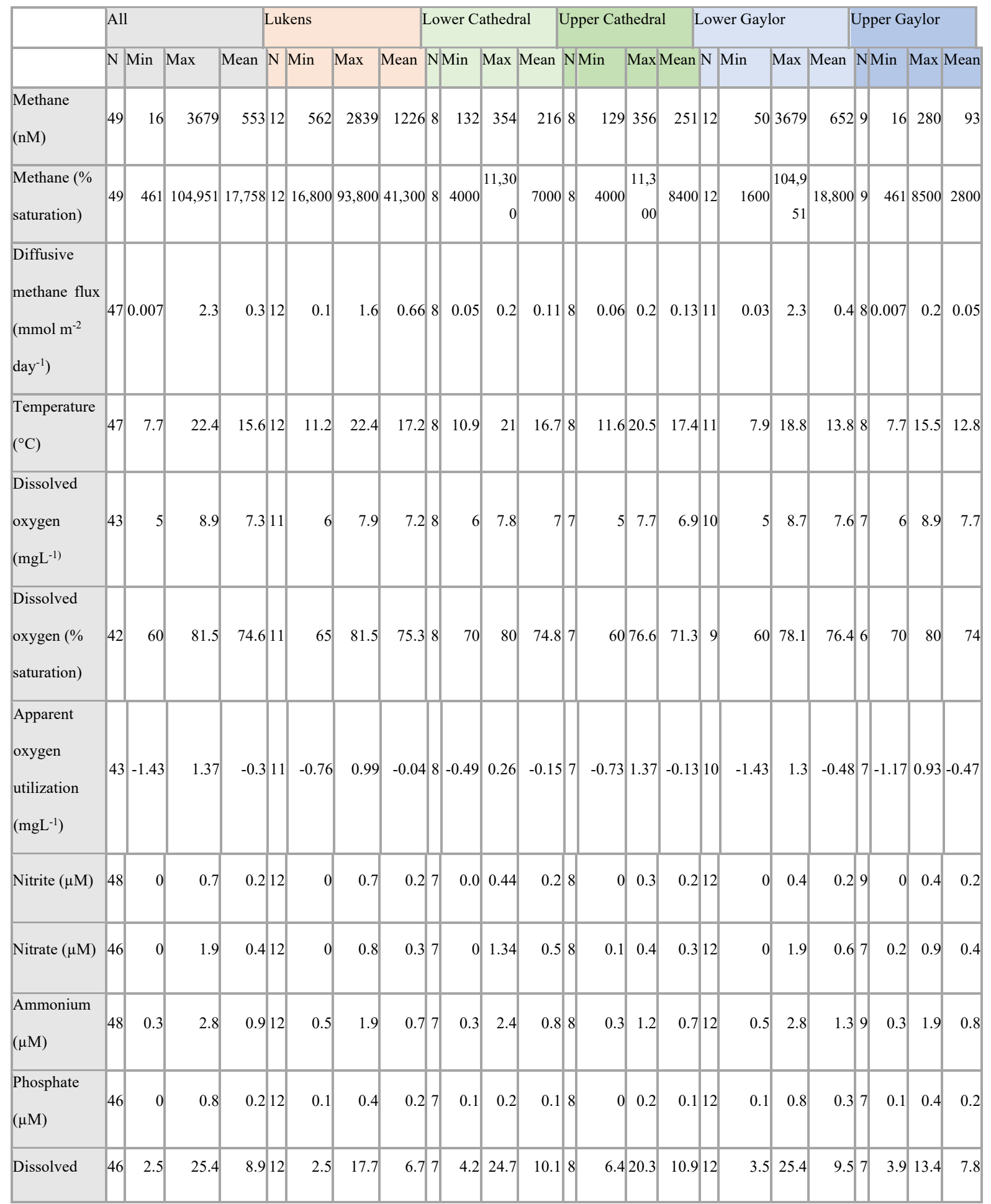




\begin{tabular}{|c|c|c|c|c|c|c|c|c|c|c|c|c|c|c|c|c|c|c|c|}
\hline $\begin{array}{l}\text { inorganic } \\
\text { nitrogen } \\
\text { :dissolved } \\
\text { inorganic } \\
\text { phosphorus }\end{array}$ & & & & & & & & & & & & & & & & & & & \\
\hline $\begin{array}{l}\text { Dissolved } \\
\text { organic } \\
\text { carbon } \\
\left(\mathrm{mgL}^{-1}\right)\end{array}$ & 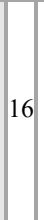 & 1 & 10.7 & 2.5 & 4 & 2.5 & 10.7 & \begin{tabular}{l|l}
5 & 4
\end{tabular} & 1.4 & 2.78 & 1.93 & 1.65 & 1.97 & 1.8 & 4 & 1.3 & 2.6 & 1.71 & 1 \\
\hline 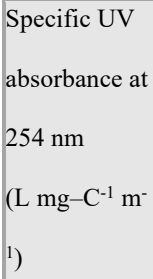 & 16 & 0.5 & 2.7 & 1.6 & 4 & 0.5 & 1.9 & 1.54 & 1.2 & 2.36 & \begin{tabular}{l|l|}
1.9 & 3
\end{tabular} & 1.8 & 2.3 & 2.3 & 4 & 0.9 & 1.3 & $\begin{array}{lll}1.1 & 1\end{array}$ & 1.5 \\
\hline Elevation (m) & 49 & 2489 & 3185 & 2891.3 & & & & 2489 & & & 2815 & & & 2905 & & & & 3115 & 3185 \\
\hline $\begin{array}{l}\text { Maximum } \\
\text { depth } \\
\text { sampled (m) }\end{array}$ & 49 & 3 & 13 & 8.2 & & & & 5 & & & 11 & & & 3 & & & & 13 & 8 \\
\hline
\end{tabular}


Table 2. Multi-linear regression models for methane $\left(\mathrm{CH}_{4}\right)$ surface concentrations as a function of environmental parameters measured in five Sierra Nevada montane lakes. Abbreviations: $\mathrm{NO}_{2}{ }^{-}=$nitrate and DIN:DIP $=$dissolved inorganic nitrogen to dissolved inorganic phosphorus ratio.

\begin{tabular}{|l|l|l|l|l|}
\hline Lakes & Equation & $\boldsymbol{R}^{2}$ & P-value & $\mathbf{n}$ \\
\hline All Lakes & Predicted $\ln \left(\mathrm{CH}_{4}\right)=5.650-$ & 0.39 & $<0.005$ & 49 \\
& $0.003($ Elevation $)$ & & \\
\hline $\begin{array}{l}\text { Mid-elevation cluster } \\
\text { Lower and Upper }\end{array}$ & Predicted $\ln \left(\mathrm{CH}_{4}\right)=6.079$ & & \\
Cathedral) & $+0.082($ Temperature $)-$ & 0.90 & $<0.0005$ & 27 \\
\hline Upper-elevation cluster & Predicted $\ln \left(\mathrm{CH}_{4}\right)=5.128-$ & & \\
$(<3000$ m) (Lower and & $0.022($ Elevation $)+0.092(\mathrm{DIN}: \mathrm{DIP})$ & & & \\
Upper Gaylor) & & & & \\
\hline
\end{tabular}




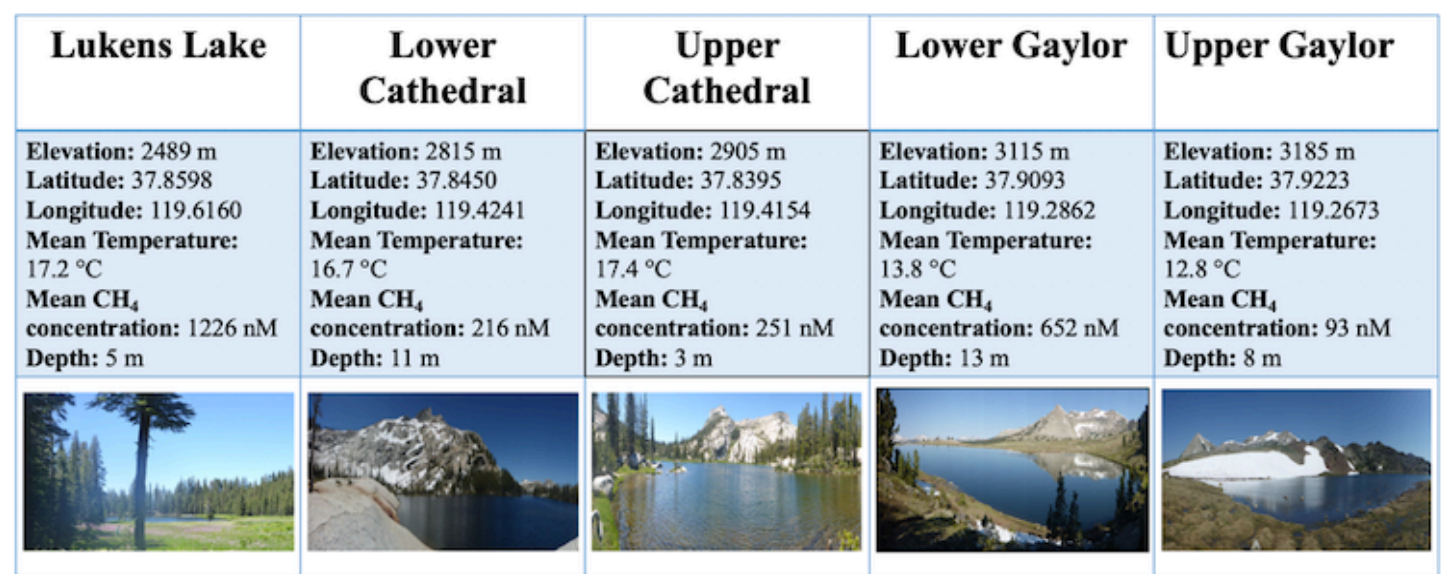

Figure 1. Morphology and environmental characteristics of five temperate montane

lakes in the Sierra Nevada, California, USA. Depth represents the maximum depth observed in each lake. Mean surface temperature and methane concentration were calculated over the sampling period July-October 2016 and July-October 2017. 

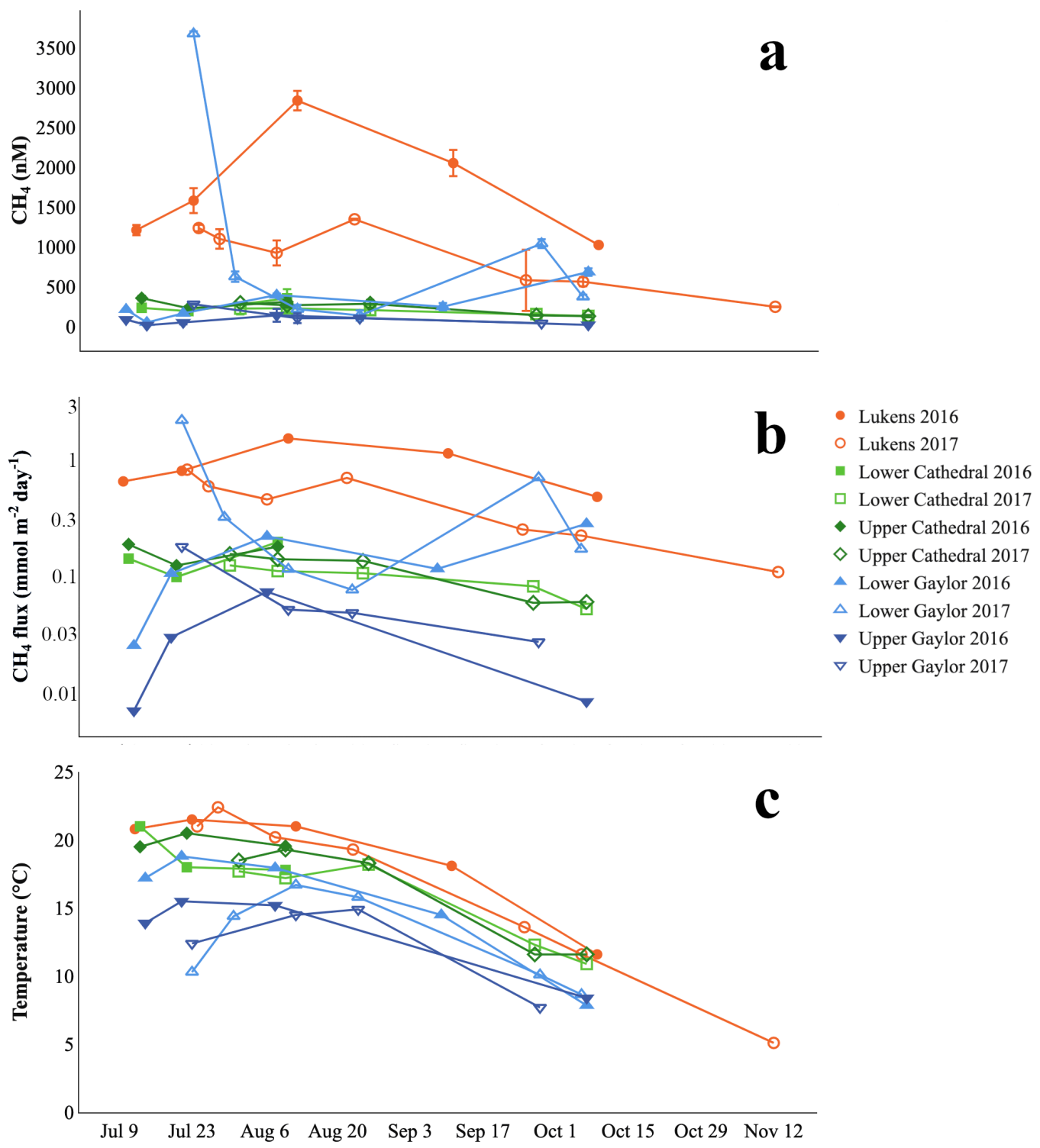

Figure 2. a) Dissolved methane concentrations (error bars represent standard deviation of triplicate water samples), b) methane effluxes (natural $\log$ transformed $\mathrm{CH}_{4}$ diffusive flux), and c) water temperature in five temperate montane lakes in the Sierra Nevada, California, USA. Colored symbols denote different lakes sampled in 2016 (open symbols) and 2017 (closed symbols), with the date of sampling along the horizontal axis 


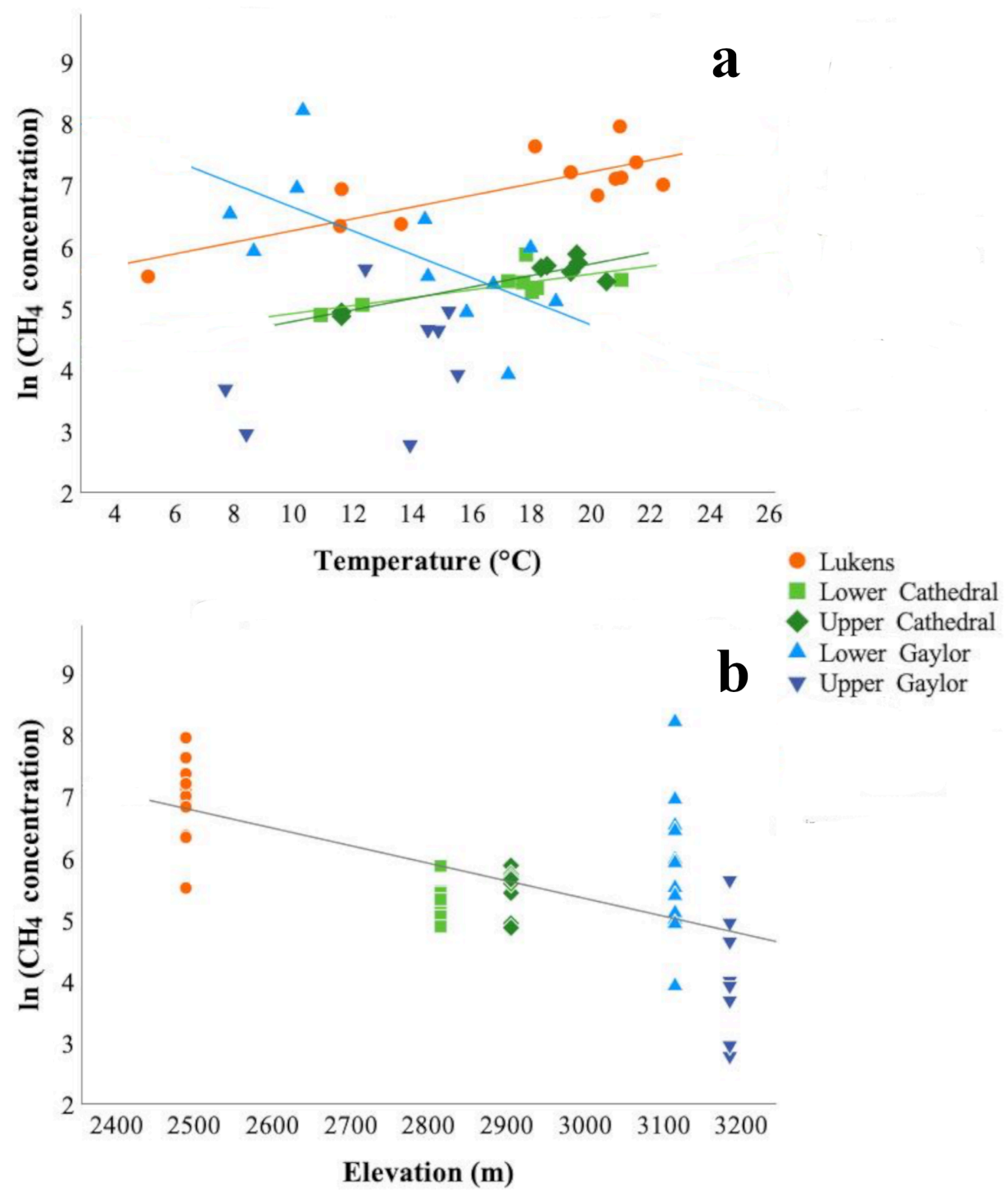

Figure 3. Dissolved methane concentrations in surface water (natural log transformed $\mathrm{CH}_{4}$ concentrations) as function of a) temperature, and b) elevation for the five temperate montane lakes sampled in the Sierra Nevada, California, USA. Colored symbols denote different lakes sampled. Colored lines represent significant linear relationships for individual lakes (Lukens: $\ln \left(\mathrm{CH}_{4}\right)=5.31+0.1 *$ Temperature; Lower Cathedral: $\ln \left(\mathrm{CH}_{4}\right)=4.27+0.06 *$ Temperature, Upper Cathedral: $\ln \left(\mathrm{CH}_{4}\right)=3.85$ $+0.09 *$ Temperature; and Lower Gaylor: $\ln \left(\mathrm{CH}_{4}\right)=8.54-0.19 *$ Temperature). Black line represents a significant linear relationship across all lakes $\left(\ln \left(\mathrm{CH}_{4}\right)=5.650\right.$ $0.003 *$ Elevation) 


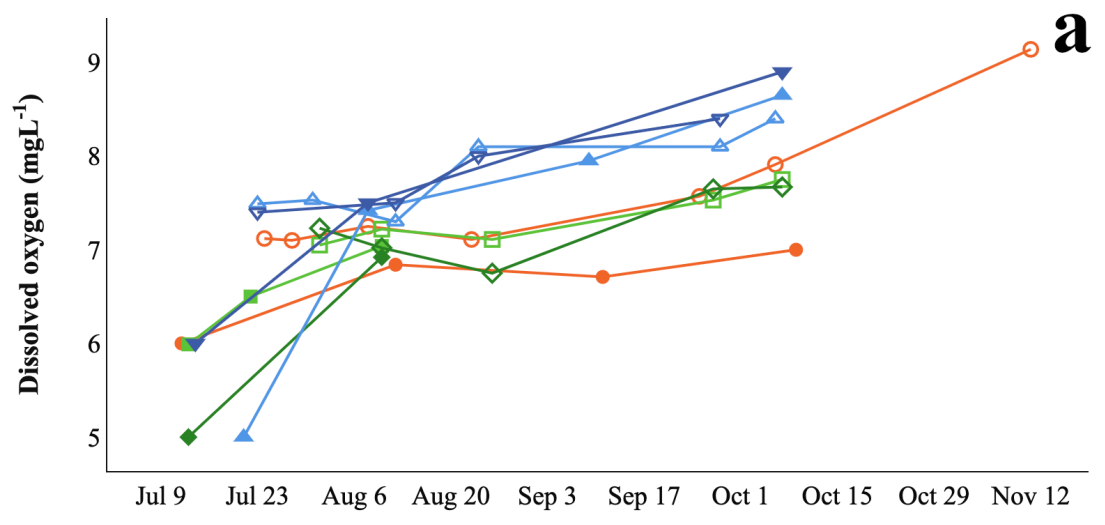

- Lukens 2016

- Lukens 2017

- Lower Cathedral 2016

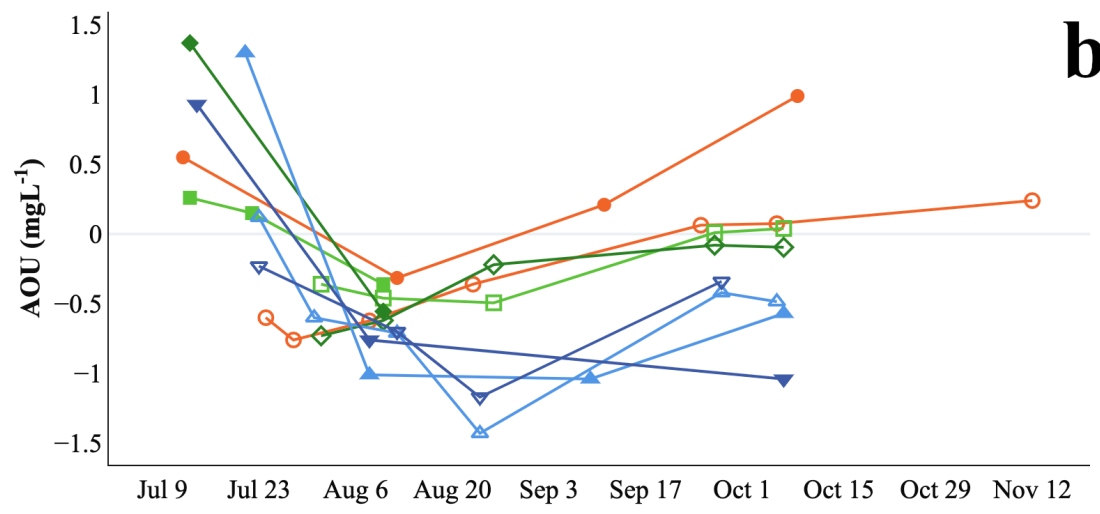

$\square$ Lower Cathedral 2017

D Upper Cathedral 2016

$\diamond$ Upper Cathedral 2017

- Lower Gaylor 2016

$\triangle$ Lower Gaylor 2017

$\checkmark$ Upper Gaylor 2016

$\nabla$ Upper Gaylor 2017

Figure 4. a) Dissolved oxygen concentrations and b) Apparent Oxygen Utilization (AOU) of five temperate montane lakes in the Sierra Nevada, California, USA. Colored symbols denote different lakes sampled in 2016 (open symbols) and 2017 (closed symbols), with the date of sampling along the horizontal axis 

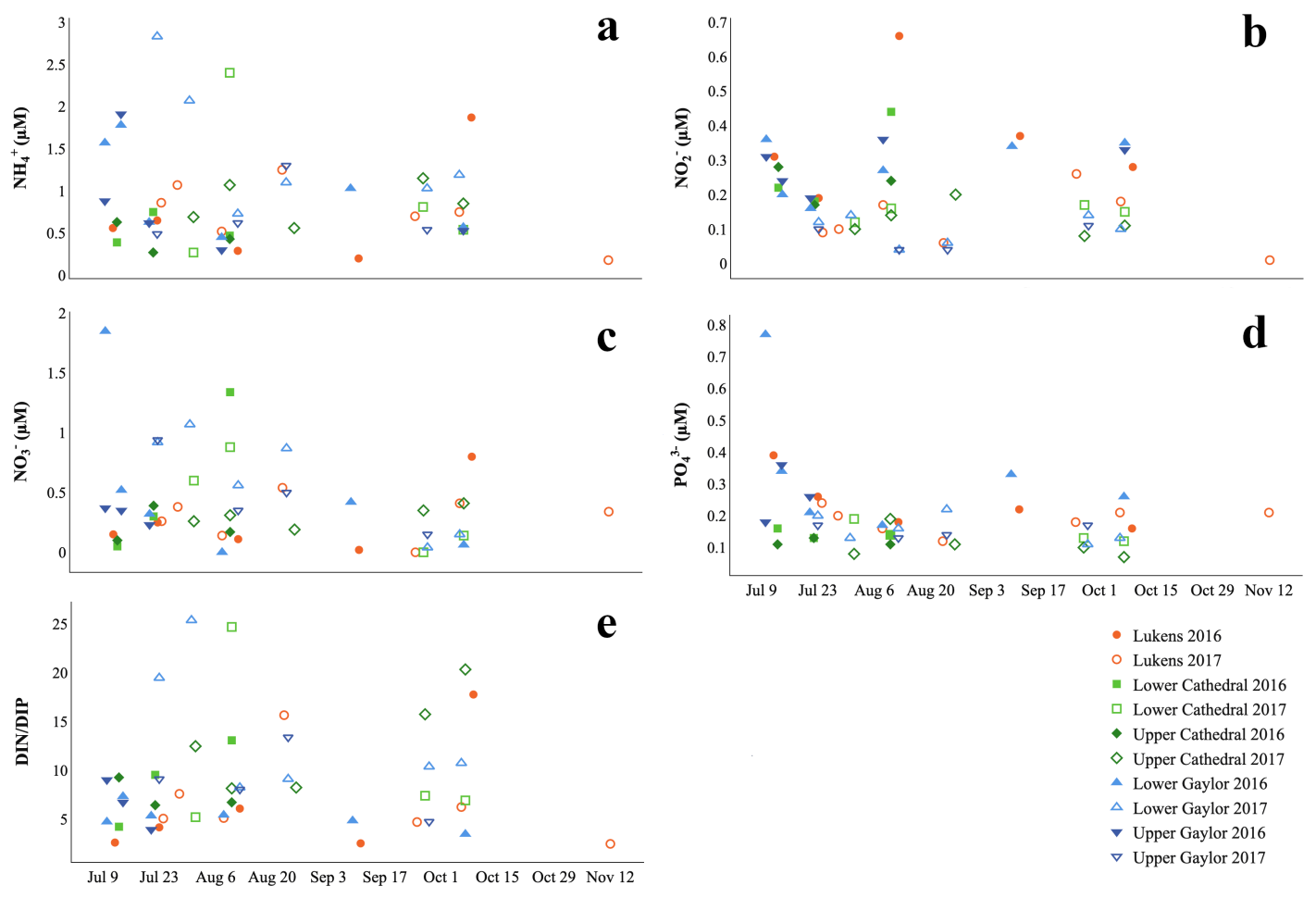

Figure 5. Inorganic nutrients concentrations: a) Ammonium, b) Nitrite, c) Nitrate, d)

Phosphate, and e) Dissolved inorganic nitrogen : dissolved inorganic phosphorus ratios for five temperate montane lakes in the Sierra Nevada, California, USA. Colored symbols denote different lakes sampled in 2016 (open symbols) and 2017 (closed symbols), with the date of sampling along the horizontal axis. 